\title{
Writing Women's Agency into the History of the Federal Republic: “1968," Historians, and Gender
}

\author{
Christina von Hodenberg
}

\begin{abstract}
To a large extent, master surveys of the Federal Republic's history have failed to weave into their narratives the rise of female emancipation or challenges to male domination. This article addresses the reasons for this failure, as well as the implications of its reversal. It analyzes the role of women activists during West Germany's "1968," underlining the gender bias of common narratives of the West German Sixties. The addition of feminist agency to West German history necessarily changes the definition of "success" in the Westernization narrative of the Federal Republic, and also the way in which we define generations and engage in public forms of commemoration.

Die Emanzipation der Frauen und die Infragestellung männlicher Dominanz spielen in den Überblickswerken zur Geschichte der Bundesrepublik nur eine untergeordnete Rolle. Warum dies so ist, und welche Folgen eine Umkehr dieser Tendenz hätte, ist Thema dieses Aufsatzes. Am Beispiel feministischer Aktivistinnen des westdeutschen "1968” wird aufgezeigt, wie geschlechtsspezifisch verzerrt die gängigen Narrative der Protestbewegung und des Wertewandels in den 1960er Jahren sind. Sobald wir die Narrative der westdeutschen Geschichte mit feministischer "agency" zusammendenken, verändert sich notwendigerweise die Definition von "Erfolg" in der "Erfolgsgeschichte" der Bundesrepublik. Zudem werden die Kategorien des "Westens" und der "Verwestlichung", der "politischen Generation" und des "Generationskonflikts" als geschlechtsspezifische Konstrukte erkennbar, die bislang eine männliche Perspektive in der Geschichtsschreibung wie in der öffentlichen Erinnerungskultur privilegiert haben.
\end{abstract}

$\mathrm{T}$ HE emancipation of women was one of the biggest changes transforming postwar West German society after 1945, and, indeed, Germany throughout the whole of the twentieth century. The change in gender relations was a long, uneven process that included setbacks and several dynamic thrusts of acceleration. The Federal Republic of Germany was, in this respect, no different from many other highly industrialized societies. Still, much of the historiography on postwar Germany has failed to address the issue adequately and to weave the political actions of women and the rise of female emancipation into its master narratives. This article addresses the reasons for this failure, but also the implications of its reversal. It argues that the addition of feminism to West German history necessarily changes the agents driving change, but also the definition of "success" in the teleological Westernization narrative of the Federal Republic. The first part engages critically with the omission of female agency in the scholarship on postwar Germany. The second part focuses on a concrete example, based on original research: the role of women activists during West Germany's unrest in the 1960s. The case of " 1968 " underscores the need to rewrite the master narratives of the West German Sixties, but also of postwar West German history in general.

For their invaluable feedback on this article, I am grateful to Ulrike Weckel, Ute Frevert, Frank Biess, Astrid M. Eckert, and the anonymous reviewers. 
Not coincidentally, all historians who have tackled the grueling task of writing (in German) large-scale national histories of post-1945 Germany have thus far been men. Speculating on the reasons for this, Ute Frevert has emphasized the underlying quest for honor and fame within the German profession. Naming Hans-Ulrich Wehler, Thomas Nipperdey, Heinrich August Winkler, and other colleagues, Frevert sees "a specific form of male authorship" at work, where historiography becomes a performative contest among males who compete for power, honor, and political impact. She compares the authors to long-distance runners who try to outdo each other with single-authored volumes of a thousand pages or more. Like generals in the military, they see "history as a battlefield on which troops are deployed against each other ... and where one thinks in terms of victory and defeat."1 The extent to which the German historical profession was and is dominated by men was also highlighted by Lyndal Roper in her keynote address for the 2014 Historikertag. Roper took her German colleagues to task for failing to integrate gender perspectives into mainstream scholarship, and contrasted the situation unfavorably with the Anglo-American setting. She diagnosed a "hidden gender hierarchy" (verborgene Genderhierarchie) in the field, stressing that the underrepresentation of female tenured professors (4 per cent in 1992, 12.6 per cent in 2002) was particularly acute in the fields of modern and contemporary history. ${ }^{2}$ Indeed, this pattern reaches back decades. Ever since the first female history professors entered academia in Germany, they had disproportionately been hired in specialized subfields such as ancient, medieval, Eastern European, and nonEuropean history - "not in modern and contemporary history, which is particularly important for the production of national "master narratives."'3

A male perspective thus shapes the "master surveys" (Meistererzählungen) of modern German history, mostly unintentionally. To a large extent, existing studies on women's and gender history have not been incorporated into the weighty surveys of national history. To a lesser extent, the authors also bypass scholarship on areas often still seen as "feminized," e.g., the history of family and kinship, private lives and emotions, sexuality and the body, or household economies. When a political history approach is taken, "politics" is often still understood in a narrow sense, relating to the state, its institutions, and the public sphere. In approaches more in tune with structural history, the "general" structures deemed worthy of attention largely exclude gender, as well as women's and family issues, because these are seen as somehow "special" and less relevant. ${ }^{4}$ Therefore, gender relations, masculinity and

\footnotetext{
${ }^{1}$ Ute Frevert, “'I have often wondered at the person's courage' oder: Mut und Ehre der Meistererzähler," paper delivered at Bielefeld University, Sept. 11, 2015. I thank Ute Frevert for a copy of her unpublished paper.

${ }^{2}$ Lyndal Roper, "Frauen in der Geschichtswissenschaft 1982-2012," keynote address, Deutscher Historikertag, Göttingen, Sept. 25, 2014. I thank Lyndal Roper for a copy of her unpublished address. The cited numbers omit untenured junior and visiting professorships. If these are included, the number rises to 27 per cent in 2012; see Karen Hagemann, "Gleichberechtigt? Frauen in der bundesdeutschen Geschichtswissenschaft,” Zeithistorische Forschungen 13, no. 1 (2016): 134.

${ }^{3}$ Roper, "Frauen," 118.

${ }^{4}$ See Karin Hausen, "Die Nicht-Einheit der Geschichte als historiographische Herausforderung: Zur historischen Relevanz und Anstößigkeit der Geschlechtergeschichte," and Thomas Kühne, "Staatspolitik, Frauenpolitik, Männerpolitik: Politikgeschichte als Geschlechtergeschichte," in Geschlechtergeschichte und Allgemeine Geschichte: Herausforderungen und Perspektiven, ed. Hans Medick and Anne-Charlott Trepp (Göttingen: Wallstein, 1998), 28-32, 45, 171-231; Robert G. Moeller, "The Elephant in the Living Room: Or Why the History of Twentieth-Century Germany Should Be a Family Affair,” in Gendering
} 
femininity, the private realm, and subjectivities play only a marginal role in these much cited tomes, and rarely inform the general narrative arc and telos of the Federal Republic's development. The most recent master surveys include, for example, only minimal treatment of the history of the second wave of the women's movement.

Typically, the authors wholeheartedly acknowledge that a sea change took place in this realm, but then avoid an in-depth discussion of it. They applaud the positive impact of the feminist movement while isolating it from the general narrative. Hans-Ulrich Wehler lauds the "undeniably successful track record" and the "secular triumphal procession [Siegeszug] of female emancipation" as "one of the biggest social changes of the epoch since 1945," but only allocates to this 8 of 439 pages. ${ }^{5}$ Ulrich Herbert likewise asserts that "the women's movement was doubtless the most important" of all social movements of the time-using the same wording for both the West German and the American context-while compressing its treatment into altogether less than a single page in a book of 1451 pages. ${ }^{6}$ Whereas Heinrich August Winkler devotes only one sentence to the topic in his survey, Eckart Conze's history of the Federal Republic dedicates a mere 3 of 936 pages to the feminist wave- even though Conze's "red thread," the search for security and stability, could fruitfully have been applied to fears of emasculation and attempts to stabilize traditional gender relations. In his thirty-page chapter on the protests of the late 1960s, female actors are absent, while much is made of "1968" as a conflict between sons and fathers. "The women's movement occupies a similar niche in Konrad Jarausch's history of Europe, where it is treated in one paragraph. ${ }^{8}$ And, while Edgar Wolfrum's survey pays some attention to women's experiences, feminist activism plays no role in his take on the history of "1968" and the social movements of the 1970s. The quotations and illustrations all foreground male protagonists. ${ }^{9}$ Axel Schildt's Ankunft im Westen from 1999 discusses women's participation in the labor market but not the feminist movement. He devotes two sentences to the fact that many '68ers were female, but this does not influence his interpretation of the protests. ${ }^{10}$ In none of these cases is feminism or male dominance part of the overarching narrative.

Why do these surveys neglect the second women's movement to such an extent, bypassing a growing body of historiography on women and gender in postwar Germany? Scholarly studies on feminist activism in West Germany, and even more so on gender relations after

Modern German History: Rewriting Historiography, ed. Karen Hagemann and Jean H. Quataert (New York: Berghahn, 2007), 228-49.

${ }^{5}$ Hans-Ulrich Wehler, Deutsche Gesellschaftsgeschichte, Bd. 5: Bundesrepublik und DDR, 1949-1990 (Munich: C. H. Beck, 2008), 172, 184.

${ }^{6}$ Ulrich Herbert, Geschichte Deutschlands im 20. Jahrhundert (Munich: C. H. Beck, 2014), 844, 861, 921-22.

${ }^{7}$ Heinrich August Winkler, Der lange Weg nach Westen, Bd. 2: Deutsche Geschichte vom Dritten Reich bis zur Wiedervereinigung (Munich: C. H. Beck, 2000), 352; Eckart Conze, Die Suche nach Sicherheit: Eine Geschichte der Bundesrepublik Deutschland (Munich: Siedler, 2009), 403-5 (see also 331-60, esp. 337). Hannah Arendt is briefy cited on p. 332.

${ }^{8}$ Konrad H. Jarausch, Out of Ashes: A New History of Europe in the Twentieth Century (Princeton, NJ: Princeton University Press, 2015), 604 (cf. 589-90).

${ }^{9}$ Edgar Wolfrum, Die geglückte Demokratie: Geschichte der Bundesrepublik Deutschland von ihren Anfängen bis zur Gegenwart (Stuttgart: Klett-Cotta, 2006), 261-71, 405-6.

${ }^{10}$ Axel Schildt, Ankunft im Westen: Ein Essay zur Erfolgsgeschichte der Bundesrepublik (Frankfurt/Main: Fischer, 1999), 57-59, 187. 
1945, are readily available. ${ }^{11}$ In addition, a plenitude of primary sources informs us about contemporary women's political actions - in stark contrast to earlier periods of history, whose scholarship has nevertheless seen a more productive inclusion of gender. ${ }^{12}$ There are two reasons the dominant master narratives insufficiently integrate the existing literature on women and gender: first, institutional marginalization, and second, the gendered implications of conceptual frameworks such as "the West" and "political history."

In German academia, women's and gender history is still seen as a niche subject, rather than as an essential component of historical scholarship. As recently as 2004, the German Historikertag was held without a single panel on women's or gender history; all such session proposals had previously been rejected. In marked contrast, at the 2004 annual meeting of the American Historical Association in Washington, D.C., about a quarter of the panels in Central European and German history dealt with women or gender issues. ${ }^{13}$ Within Germany, contributions on women and/or gender in postwar German history are still overwhelmingly written by female authors, most of whom have not (or not yet) acquired one of the full professorships available at German universities. Many of these authors belong to neighboring disciplines, end up working outside Germany, or are employed on shortterm contracts and thus fill the lower ranks of the profession. Nowadays, there are only nine full history professorships fully or partly dedicated to gender history or women's history in Germany. These types of position were mostly created during the 1980s and 1990s, not least in response to vocal demands by undergraduate and graduate students, and they are currently under threat: when the incumbents retire, the lines are often cut or redefined. A recent study on the role of women and gender-themed professorships in Germany points out that these positions were closely linked to and often crucial for gender scholarship outside academia - in the form of feminist museums, archives, libraries, centers, journals, and projects. At the same time, they faced a practice of "marginalizing integration" within academia, whereby gender topics were repeatedly placed at the margins of the field and its practitioners labeled both "special" (besonders) and "inferior" (unterlegen) in internal power

\footnotetext{
${ }^{11}$ On feminist activism, see Kristina Schulz, Der lange Atem der Provokation: Die Frauenbewegung in der Bundesrepublik und in Frankreich 1968-1976 (Frankfurt/Main: Campus, 2002); Myra Marx Ferree, Varieties of Feminism: German Gender Politics in Global Perspective (Stanford, CA: Stanford University Press, 2012); Christine Thon, Frauenbewegung im Wandel der Generationen (Bielefeld: transcript, 2015); Ilse Lenz, ed., Die neue Frauenbewegung in Deutschland: Abschied vom kleinen Unterschied. Eine Quellensammlung, 2nd ed. (Wiesbaden: VS Verlag, 2010). On gender relations, see Julia Paulus, Eva-Maria Silies, and Kerstin Wolff, eds., Zeitgeschichte als Geschlechtergeschichte: Neue Perspektiven auf die Bundesrepublik (Frankfurt/Main: Campus, 2012); Eva-Maria Silies, Liebe, Lust und Last: Die Pille als weibliche Generationserfahrung in der Bundesrepublik 1960-1980 (Göttingen: Wallstein, 2010); Christine von Oertzen, The Pleasure of a Surplus Income: Part-Time Work, Gender Politics, and Social Change in West Germany 1955-1969 (New York: Berghahn, 2007); Elizabeth D. Heineman, What Difference Does a Husband Make? Women and Marital Status in Nazi and Postwar Germany (Berkeley: University of California Press, 2003); Sybille Buske, Fräulein Mutter und ihr Bastard: Eine Geschichte der Unehelichkeit in Deutschland 1900 bis 1970 (Göttingen: Wallstein, 2013); Robert G. Moeller, Protecting Motherhood: Women and the Family in the Politics of Postwar West Germany (Berkeley: University of California Press, 1996); Theresia Degener, "Der Streit um Gleichheit und Differenz in der Bundesrepublik Deutschland seit 1945," in Frauen in der Geschichte des Rechts, ed. Ute Gerhard (Munich: C. H. Beck, 1997), 871-99.

${ }^{12}$ See, e.g., the historiography on early modern European witchcraft, or on gender relations during the French Revolution.

${ }^{13}$ Karen Hagemann and Jean H. Quataert, "Gendering Modern German History: Comparing Historiographies and Academic Cultures in Germany and the United States through the Lens of Gender," in Hagemann and Quataert, Gendering Modern German History, 28-30.
} 
dynamics. ${ }^{14}$ This situation is both a reason for and a symptom of the isolation and compartmentalization of women's and gender history in the field.

Another, deeper reason for the marginalization of feminist agency in the historiography lies in the overreliance on an idealized model of the West. When the narrative telos of Western liberalism is read into the history of West Germany, historians carry with them all the baggage associated with this concept. In the introduction to this special issue, Astrid M. Eckert and Frank Biess highlight the inherent exclusions of the "Westernization" and "liberalization" approach, stressing, in particular, the legacy of Western colonial violence and slavery. But they also mention the model's emphasis on "a Western (often explicitly or implicitly male) rational enlightenment subject as the main agent in the process of democratization." ${ }^{15}$ In fact, beyond the working classes, women were the biggest group excluded by the Western project of liberalism and progress, from the emergence of early liberalism during the eighteenth century to the struggle for women's suffrage in the early twentieth century. The Western master narrative is, as a result, inherently male in several respects. It originally assigned rationality to men and irrationality to women, agency to men and passivity to women. In the normative orbit of the West, a conscious effort is required in order to imagine women driving progress. Where master narratives privilege "political" issues in the traditional sense, they tend to reproduce a male cast of actors and strictly gendered forms of political action. ${ }^{16}$ The concept of the West is therefore structurally underpinned by the foundations of patriarchy, even if this is rarely addressed openly.

If gender inequality is truly to be included in the Federal Republic's master narratives, this will lead to new questions about the country's postwar "success story," the agents of change, caesuras, and periodization. The starting point is to acknowledge that liberal Western democracy, as the norm against which the Federal Republic has typically been measured, was built on male dominance, and that there has been, to this day, a longstanding struggle against the continuing suppression and exclusion of women from the full promises of democracy and equality. Therefore, whenever historians emplot narratives of "liberalization," "democratization," or "Westernization," they need to integrate into their argument the overcoming of patriarchal structures, discourses, subjectivities, and embodiments. They could ask about the extent to which post-1945 developments were a success story for women, as well as for men. To what extent did the West German state and society retain patriarchal structures, thereby guaranteeing that husbands dominated wives? Which institutions, such as marriage and the division of labor, or cultural dichotomies (e.g., productive versus reproductive work, public versus private spheres), reinforced gender inequality? ${ }^{17}$ How and when did they change over time, and which limitations remained? Which groups challenged the patriarchal consensus and therefore deserve credit for driving progress? Which opposing groups

\footnotetext{
${ }^{14}$ Thirty-nine incumbents were interviewed for a study on the role of these gender-themed professorships; twenty-three of these positions have since been cut and additional ones rededicated to other areas. See Ulla Bock, Pionierarbeit: Die ersten Professorinnen für Frauen- und Geschlechterforschung an deutschsprachigen Hochschulen 1984-2014 (Frankfurt/Main: Campus, 2015), esp. 22.

${ }^{15}$ See the introduction to this special issue.

${ }^{16}$ Kühne, "Staatspolitik." Also see the call for a reconfiguration of the metanarrative of Western modernity in Lynn Hunt, "The Challenge of Gender: Deconstruction of Categories and Reconstruction of Narratives in Gender History," in Medick and Trepp, Geschlechtergeschichte und Allgemeine Geschichte, 15-56.

${ }^{17}$ I use the term patriarchy to describe societies structured by male dominance, even though, in the modern era, this dominance is less defined by fatherhood than by other factors. See Claudia Opitz, Um-Ordnungen der Geschlechter: Einführung in die Geschlechtergeschichte (Tübingen: diskord, 2005), 18-25.
} 
defended the status quo, why, and how successfully? The answers to these questions have an impact on the grand narrative of the postwar era by affecting the periodization of post-World War II history, with its current emphasis on the emergence of postmodernity and on a new era that began "after the boom" in the 1970s.

\section{The Female "1968"}

The following section offers a case study of women activists in the West German protest movements of the late 1960s — a form of activism that, to date, has largely been overlooked in the mainstream historiography (though there are specialist publications that deal with it). The female "1968," which includes the first stirrings of the second wave of the feminist movement, has generally been cast as a marginal byproduct of the student revolt. Women's activism has been treated in isolation from the predominantly male "1968," if it has been treated at all. Histories of the West German Sixties habitually display images of men on book covers: Rudi Dutschke, Daniel Cohn-Bendit, Fritz Teufel, and Rainer Langhans have become the icons of the rebellion. ${ }^{18}$ In the public imaginary, " 1968 " conjures up images of heated debates in overcrowded lecture halls and of student demonstrations, invariably with men at the microphones and marching in the first row. In most accounts, female "68ers function mainly as the rebels' "arm candy" - attractive attachments who brewed the coffee, sewed the flags, and typed the leaflets for their male comrades. ${ }^{19}$ Feminists such as Helke Sander, Sigrid Damm-Rüger, Silvia Bovenschen, or Florence Hervé have been all but forgotten. In the aforementioned master surveys, their names do not appear in the index, whereas Rudi Dutschke and Daniel Cohn-Bendit regularly do. These women are not even referred to in books more narrowly dedicated to the West German Sixties. ${ }^{20}$

A closer look shows that this gendered narrative of Sixties protest, the one to which we have become accustomed, is far from accurate. Ever since 1968, gendered myths developed around a male-defined "political generation" of "68ers and around the supposed conflicts between Nazi fathers and antifascist sons. Politically active women thus disappeared from the history of the Sixties, although their long-term impact on the development of West German society was arguably larger than that of their male compatriots. Once we write women back into the story, the character of "1968," its role as a caesura in postwar German history, and the concept of the " 68 er generation" all need to be reevaluated.

\footnotetext{
${ }^{18}$ See the covers, e.g., of Wolfgang Kraushaar, Achtundsechzig: Eine Bilanz (Berlin: Propyläen, 2008); Daniel Cohn-Bendit and Rüdiger Dammann, 1968: Die Revolte (Frankfurt/Main: Fischer, 2007); Norbert Frei, 1968: Jugendrevolte und globaler Protest (Munich: DTV, 2008); Martin Klimke, The Other Alliance: Student Protest in West Germany and the United States in the Global Sixties (Princeton, NJ: Princeton University Press, 2009).

${ }^{19}$ Former activists report that they were addressed as "brides of the revolution" (Susanne SchunterKleemann), "accessories" (Gretchen Dutschke-Klotz), and as "the comrade's extended arm" (Annemarie Tröger). See Ute Kätzel, ed., Die 68erinnen: Porträt einer rebellischen Frauengeneration (Berlin: Ulrike Helmer, 2008), 111; Gretchen Dutschke-Klotz, Wir hatten ein barbarisches, schönes Leben. Rudi Dutschke: Eine Biographie (Cologne: Kiepenheuer \& Witsch, 1996), 81; Siegward Lönnendonker, ed., Linksintellektueller Aufbruch zwischen "Kulturrevolution" und "kultureller Zerstörung": Der Sozialistische Deutsche Studentenbund (SDS) in der Nachkriegsgeschichte 1946-1969 (Wiesbaden: VS Verlag, 1998), 216.

${ }^{20}$ They are not listed in the indices of the surveys by Winkler, Wolfrum, Herbert, Wehler, and Conze (see notes 5-9), or in Frei, 1968, or in Götz Aly, Unser Kampf: 1968-ein irritierter Blick zurück (Frankfurt/Main: Fischer, 2008).
} 
The story of feminist activism in the late 1960s has been researched, so a brief recap should suffice. ${ }^{21}$ It started at the universities with the most politicized women in the Socialist German Student League (SDS). About a quarter of all students in 1968, and also a quarter of SDS members, were female. ${ }^{22}$ Most female students experienced routine, everyday discrimination at the university, often without being aware of it. Two to three times as many female than male students dropped out before the final exams. Eight of ten professors were convinced that women attended university only to find a husband, according to a flyer that circulated in Bonn in 1969. Indeed, as late as 1960, a representative study of West German university professors had found that 64 per cent of them were principally or mostly opposed to women students, and 79 per cent to women professors. ${ }^{23}$ Because West German women still tended to marry and have their first child by their early to midtwenties, an ill-timed pregnancy often spelled the end of a female student's academic career. Childcare facilities for under-threes were nonexistent and for over-threes scarce, and only one in five young fathers helped out with childcare tasks. ${ }^{24}$

The earliest protests by female "68ers grew out of dissatisfaction with this situation. It was disproportionately mothers of small children who began to organize themselves and voice their concerns, such as Helke Sander, Sarah Haffner, Frigga Haug, and Karin Adrian in West Berlin, or Florence Hervé in Bonn. ${ }^{25}$ Significantly, many female activists had a transnational background that included experience with countries where childcare was more readily available and career women were seen more favorably than in West Germany. Sander could compare the situation in West Germany with that of Finland, Haffner with that of Britain, Gretchen Dutschke-Klotz with that of the United States, and Hervé with that of France. ${ }^{26}$ These and other women now gathered in informal reading groups (in West Berlin and Bonn since 1967, in Frankfurt since 1968) or in women's communes (in Munich since 1968). Over time, they founded organized interest groups, such as the Berlin Council for the Liberation of Women (Aktionsrat zur Befreiung der Frauen), the Frankfurt Hag Council (Weiberrat), and the Bonn Emancipation Study Group (Arbeitskreis Emanzipation). They wrote and circulated leaflets, initially aimed mainly at fellow female students. Many of these flyers called the "machos" of the New Left to task for their patronizing attitude toward women who wanted to be part of the political discussion and action. ${ }^{27}$ A common complaint was that the men dominated debate: "All the time there

\footnotetext{
${ }^{21}$ For more on this, see Christina von Hodenberg, Das andere Achtundsechzig: Gesellschaftsgeschichte einer Revolte (Munich: C. H. Beck, 2018), 103-50; Ute Kätzel, "Vorwort,” in Kätzel, Die 68erinnen, 9-18; Schulz, Der lange Atem der Provokation; Elisabeth Zellmer, Töchter der Revolte? Franenbewegung und Feminismus der 1970er Jahre in München (Munich: Oldenbourg, 2011).

${ }^{22}$ Florence Hervé, Studentinnen in der BRD: Eine soziologische Untersuchung (Cologne: Pahl-Rugenstein, 1973), 20; Hagemann, "Gleichberechtigt?," 115; for the SDS in West Berlin, see Andrea Wienhaus, Bildungswege zu "1968”: Eine Kollektivbiografie des Sozialistischen Deutschen Studentenbundes (Bielefeld: transcript, 2014), 102.

${ }^{23}$ Hervé, Studentinnen, 82-83; University Archive Bonn, Kl. Slg. 331, Dokumentation “arbeitskreis emanzipation," leaflet, Oct. 1969; Hagemann, "Gleichberechtigt?," 116-17.

${ }^{24}$ Elisabeth Pfeil, Die 23jährigen: Eine Generationenuntersuchung am Geburtenjahrgang 1941 (Tübingen: Mohr Siebeck, 1968), 84-88; Sven Reichardt, Authentizität und Gemeinschaft: Linksalternatives Leben in den Siebziger und frühen Achtziger Jahren (Berlin: Suhrkamp, 2014), 722-45; Hervé, Studentinnen, 76-85.

${ }^{25}$ Hodenberg, Das andere Achtundsechzig, 116-20.

${ }^{26}$ See Kätzel, Die 68erinnen, 163-64, 282; Florence Hervé, in discussion with the author, May 18, 2017.

${ }^{27}$ Lenz, Die neue Frauenbewegung, 50-59; University Archive Bonn, Kl. Slg. 331, Dokumentation "arbeitskreis emanzipation"; Zellmer, Töchter der Revolte?, 82-88.
} 
were intimidating remarks" (Elsa Rassbach); "the men often laughed" at women who spoke up (Gretchen Dutschke-Klotz); the SDS cultivated "repressive structures of communication" (Mona Steffen). Beatrix Novy reported "this ubiquitous gap" at the University of Cologne: "the [male] comrades always talked very loudly and very much, and the women very little." 28 The women responded by opting for gender separatism, organizing themselves in femaleonly groups.

The sense of unease at the patriarchal demeanor of the male activists did not stop there. The Frankfurt Weiberrat famously mocked their male comrades for their sexual conquests with a leaflet titled "Liberate the socialist bigwigs from their bourgeois dicks" (Befreit die sozialistischen Eminenzen von ihren bürgerlichen Schwänzen). In this much-cited but rare example, female "68ers explicitly linked the sexism of SDS men to the pressures many women felt to comply with the demands of a male-dominated sexual revolution. ${ }^{29}$ Much more commonly, though, women activists protested not the men's sexual practices but rather their avoidance of family work and household chores. Even in the experimental hothouse of Berlin's Kommune 1, female members complained about patriarchally inflected everyday interactions. As Dagmar Seehuber put it, "The patriarchal structure of society expressed itself particularly strongly in this commune ... That's because the men categorically denied that they themselves had to change. Their actions were far from the theoretical blueprint they possessed." 30 Karin Adrian reported tense weekly meetings in other communes, with "the main issue being that, once again, nobody had done the cleaning." Hedda Kuschel "noticed" in the Wieland commune "how often the men ducked household chores." 31 Helke Sander, who lived in a ten-room shared flat in West Berlin with her son, experienced incessant conflict over mundane, everyday chores because "the idea of cleaning a toilet by themselves was unfathomable" to the men. This eventually prompted the women to lock the men into a room for a night until they promised to do a better job of sharing the work. ${ }^{32}$

A key text read by many feminists at the time was Karin Schrader-Klebert's essay "The cultural revolution of woman," which appeared in June 1969, in Kursbuch. It interpreted a woman's role in the household as slavery and as disenfranchisement. Household duties were now theoretically conceived of as instruments to repress and stultify women intellectually, as a ritual of daily humiliation, and as a "material cult for the man" (Kult der Dinge für den Mann). ${ }^{33}$ As a flyer from a women's center in Berlin stated: "We only achieved recognition where we are most constricted: in the household and family. Where we are locked in the two-to-three bedroom apartment in order to polish it constantly." 34

\footnotetext{
${ }^{28}$ Kätzel, Die 68erinnen, 65-66, 281; Schulz, Der lange Atem der Provokation, 88; "Meine Geschichte-die 68er Generation," dir. Carsten Günther, Phoenix, Sept. 21, 2008.

${ }^{29}$ Lenz, Die neue Frauenbewegung, 64-65.

${ }^{30}$ Kätzel, Die 68erinnen, 218.

${ }^{31}$ Ibid., 246, 130.

${ }^{32}$ Michael Sontheimer, "Revolte in der Revolte," Der Spiegel, April 7, 2018.

${ }^{33}$ Karin Schrader-Klebert, "Die kulturelle Revolution der Frau,” Kursbuch 17 (1969): 10, 28-29.

${ }^{34}$ Reichardt, Authentizität und Gemeinschaft, 606. For a similar flyer from 1971, see Universitätsarchiv Bonn, Kl. Slg. 331, Dokumentation "arbeitskreis emanzipation." By 1976, unpaid domestic work had become a major topic for the German feminist movement; see Gisela Bock and Barbara Duden, "Arbeit aus Liebe-Liebe als Arbeit: Zur Entstehung der Hausarbeit im Kapitalismus," in Frauen und Wissenschaft: Beiträge zur 1. Sommeruniversität für Frauen, ed. Gruppe Berliner Dozentinnen (Berlin: Courage-Verlag, 1977), 118-99.
} 
The first event of the second feminist movement covered by several print media was a clash between men and women at an SDS conference in Frankfurt in September 1968, when Helke Sander delivered a brave speech attacking male students for taking part in "the social oppression of women in an individual way ..., in the private sphere." Fellow SDS member Sigrid Damm-Rüger then threw tomatoes at the male delegates, who attempted to avoid any discussion of Sander's theses. Konkret columnist Ulrike Meinhof, a mother of twins trying to reconcile a journalistic career with family obligations, called these tomatoes the harbinger of things to come:

The woman who threw tomatoes, and the woman who supplied the reasons for doing so ... acted for countless women .... And they couldn't have cared less if what they had to say measured up to the usual theoretical level of discourse expected in the SDS ... The Berlin women who intervened in Frankfurt no longer want to cooperate. They bear the entire burden of raising children ... They no longer want to suffer insulting comments for not having a good education, or only a partial education, or not be able to work in their professions because they are raising children. ${ }^{35}$

One of the first decisions taken by the new women's groups in 1968 was to initiate selfgoverned Kinderläden. These new nurseries were intended not only to free up time for the mothers to study and be politically active, but also to champion a less authoritarian style of education. The model quickly spread across the country, with Kinderläden springing up everywhere. But during the first years of the new nurseries, leftist women and men fought over their control. The West Berlin Council for the Liberation of Women (Aktionsrat zur Befreiung der Frauen) was challenged by a new Central Council of Socialist Nurseries (Zentralrat der sozialistischen Kinderläden). The latter had been set up by young fathers who prioritized not the liberating effect of childcare on the mothers but rather the ideological experiment of raising a new generation of revolutionaries. The men wanted the children to be freed from the constraints of capitalism and bourgeois family values, and this theoretical zest made the nurseries, according to Helke Sander, "into a political project that demanded full-time commitment" instead of serving to save women time for other pursuits. ${ }^{36}$ This gendered battle over the Kinderläden mirrored a fundamental conflict within the New Left over revolutionary priorities. Most male rebels saw the plight of women as a "minor contradiction" (Nebenwiderspruch) that would automatically be resolved once the "major contradiction" (Hauptwiderspruch) had been eradicated, i.e., once the campaign against capitalism had been won. ${ }^{37}$ This was, by no means, the only internal battle in which female activists found themselves. From 1969 onward, several painful splits developed within the feminist movement: between communist, socialist, and reformist women, and between those who stressed biological gender difference and those who did not. ${ }^{38}$

\footnotetext{
${ }^{35}$ Ulrike Meinhof, Everybody Talks About the Weather. We Don't: The Writings of Ulrike Meinhof, ed. Karin Bauer, trans. Luise von Flotow (New York: Seven Stories Press, 2008), 209-11.

${ }^{36}$ Kätzel, Die 68erinnen, 168. For Kinderläden, see Till van Rahden, "Eine Welt ohne Familie: Der Kinderladen als ein demokratisches Heilsversprechen," in Autorität: Krise, Konstruktion und Konjunktur, ed. Till van Rahden, Oliver Kohns, and Martin Roussel (Paderborn: Wilhelm Fink, 2016), 255-82; Reichardt, Authentizität und Gemeinschaft, 728-81; Zellmer, Töchter der Revolte?, 68-78.

${ }^{37}$ For examples, see Lönnendonker, Linksintellektueller Aufbruch, 209, 214, 231.

${ }^{38}$ See Kätzel, Die 68erinnen, 192-93; Schulz, Der lange Atem der Provokation, 93-96, 149-50; Rosemarie Nave-Herz, Die Geschichte der Frauenbewegung in Deutschland (Opladen: Leske + Budrich, 1982), 56-58.
} 
The politically active women of 1968 had gone through SDS schooling, and thus employed symbolic forms of direct action to attract media coverage. Remarkably, their actions often drew on elements from the traditionally female spheres of household and caring duties. Damm-Rüger, for example, threw tomatoes intended for a soup she was planning to make for supper that night. Annette Schwarzenau besmirched the walls of the editorial offices of the illustrated weekly Stern with the contents of soiled Kinderladen diapers, and she helped nurses protest against the bonnets they were ordered to use to cover their hair. A group around Helke Sander in West Berlin incited kindergarten teachers to strike, and the West Berlin Kommune 99 initiated a "children's demonstration" with balloons and puppet theatre. ${ }^{39}$

Yet, while public actions by female '68ers were often playful and creative, their private struggles could be painfully mundane and repetitive. Women's demands for a rapid change in their everyday gendered habits were bound to meet with resistance by their partners, because most men of the "68er generation had grown up with a sense of entitlement. In three-quarters of all families with multiple children born around 1940, boys had to help much less around the house than girls did. This was a male privilege that almost all the boys, but only half the girls, perceived to be "natural." 40 In this same age cohort, gendered battles over cleaning, grocery shopping, and childcare were now fought out well beyond the walls of communes. A survey from 1964 reported that young women did nine-tenths or more of all household chores in 93 percent of all cases, but pressure by women (and cooperation by men) began slowly to change the situation over the course of the next decades. ${ }^{41}$

The private activism of female "68ers challenged their partners and husbands in different ways. The campaign in the home, together with a certain disdain for the bourgeois institution of monogamy and the limited availability of state-sponsored childcare, resulted in many relationships tail-spinning into crisis. A contemporary sociologist spoke of the common "experiences of failure" and the "high psychological costs" paid by "all those involved in the feminist movement." 42 In the urban alternative milieus of the 1970 s, where feminism had made significant inroads, heterosexual relationships were typically referred to as Beziehungskisten, i.e., relationships under construction. Experienced as being besieged by all kinds of problems, the latter were variously characterized as "relationship prisons" (Beziehungsknast), "daily petty wars" (täglicher Kleinkrieg) and "crisis carousels" (Krisenkarussell). ${ }^{43}$ Many "68ers of both genders rejected the institution of marriage not just for its bourgeois connotations, but also because it was seen as a pillar of patriarchy. A 1969 report about the Berlin Kinderladen founded by Kommune 2 stated the following: "Without exception, all nuclear families involved in the Kinderladen project experienced strong friction between the married partners from the outset. During our cooperation in the Kinderladen, everyone actually realized that these marriages were unsustainable." 44

\footnotetext{
${ }^{39}$ Kätzel, Die 68erinnen, 48-49, 51-54, 171-72; "Vereinigt euch,” Der Spiegel, June 9, 1969.

${ }^{40}$ Pfeil, Die 23jährigen, 82. West German girls in these age cohorts often felt that their brothers were treated preferentially; see Lu Seegers, Vati blieb im Krieg: Vaterlosigkeit als generationelle Erfahrung im 20. Jahrhundert (Göttingen: Wallstein, 2013), 196.

${ }^{41}$ Pfeil, Die 23jährigen, 83-84.

${ }^{42}$ Nave-Herz, Die Geschichte der Frauenbewegung, 80.

${ }^{43}$ Sven Reichardt, "Von 'Beziehungskisten' und 'offener Sexualität," in Das alternative Milieu: Antibürgerlicher Lebensstil und linke Politik in der Bundesrepublik Deutschland und Europa 1968-1983, ed. Sven Reichardt and Detlef Siegfried (Göttingen: Wallstein, 2010), 267-68, 280.

${ }^{44}$ Kommune 2, "Kindererziehung in der Kommune," Kursbuch 17 (1969): 174.
} 
A peek into one marriage shows why. Regine Walter-Lehmann was an activist in the West Berlin feminist movement of the 1970s and later became an editor of the tageszeitung. As a student, she had married Joachim Lehmann, and both were active in the New Left. At the beginning of their relationship, she typed her husband's masters thesis, but she soon saw in him "the sluggish object of a reeducation offensive with regard to children, kitchen, and cleaning duties." She subjected him to, in his words, "disputes at the kitchen table, lasting into the early morning hours, about female and male patterns of perception, thought, and writing"- - disputes "that could never be resolved." After the birth of a daughter, Joachim urged Regine to quit an intellectually exciting but poorly paid job as an assistant dramaturge at a theater. Regine complied, but she now experienced the family apartment as a "prison": "I will never forgive myself for giving up such a coveted job which I loved so dearly," she wrote in her diary. "It eats and eats away at me ... Instead I played at wife-gone-wild and got myself into an extramarital affair. Typical, unfortunately. And bloody stupid, too." Although she loved her husband, she simply could not overcome her opposition to

this Klein-Family-Life ... it makes me sick ... Daughter gets to the heart of it: she formulates her wishes in a provocatively conservative way. Mommy, daddy, child, all together! Of course, she senses my tendency to take flight and is aggressive and anxious. If that continues for a few years, I won't exist any longer. I have to do something new, something different!

To break out of "this old-fashioned, wifely perspective" that she had "never wanted," Regine eventually moved out of the apartment, took up a new job, and became a "three-day mum" to her daughter for several years. Regine acknowledged how "wretched" she felt telling her daughter that she "would share the fate of her many comrades in the Schülerladen who have a four-day mum and a three-day dad," but did not see an alternative. In the milieu to which the Lehmanns belonged, their separation was not unusual. In the Kinderladen her daughter attended, only two children were raised by parents who lived together. ${ }^{45}$

Walter-Lehmann's actions were a protest against the traditional gender norms that she felt confined her. Emancipatory battles like hers played out in the private realm and thus were less visible in the public sphere. The new feminist movement enriched politics by making the private political, but the far-reaching impact of women's private struggles remained consistently underrepresented in contemporary debates. There was a deep-seated expectation that revolutions could only take place in public, and that revolutionaries could only be male. The police, for example, typically released female protesters immediately. When Dagmar Seehuber was arrested with other members of Kommune 1 for allegedly having planned to assassinate US Vice President Hubert Humphrey, who was to visit West Berlin in April 1967, the officer checking her papers told her that the "women can all go home." Gretchen Dutschke-Klotz was similarly once freed from prison after having been arrested at a demonstration together with Rudi. She was sent home with an explicit order: to bring back food for her husband. ${ }^{46}$

Female activists were mainly perceived as "tarts [Bräute] of the revolt" - an epithet media reporters and editors often used to belittle the women. ${ }^{47}$ Der Spiegel mocked the

\footnotetext{
${ }^{45}$ Joachim Lehmann, "Matriarchat, nicht Proletariat! Ein Rückblick auf die feministische Revolte der siebziger Jahre," in Weiblichkeit als politisches Programm? Sexualität, Macht und Mythos, ed. Bettina Gruber, Heinz-Peter Preußer, and Udo Franke-Penski (Würzburg: Königshausen and Neumann, 2005), 41-45.

${ }^{46}$ Kätzel, Die 68erinnen, 207, 286.

${ }^{47}$ See Ingo Cornils, Writing the Revolution: The Construction of "1968” in Germany (Rochester, NY: Camden House, 2016), 140.
} 
"sleep-deprived brides of the revolution," who took the pill, wore eye shadow, and carried tampons in their purses. ${ }^{48}$ In 1968, West German television did not screen footage of Sander's speech or the subsequent tomato toss, for the event's significance was not recognized. Instead, much media attention centered on sexualized images of women in the movement. Uschi Obermaier, a model who temporarily joined Rainer Langhans in Kommune 1, became the pin-up of the revolt. She posed bare-breasted for the cover of the illustrated weekly Stern and made headlines with the affairs she had with rock musicians. The most well-known woman of the German student movement was anything but a feminist. ${ }^{49}$

\section{Gendered Commemoration}

In contrast to Uschi Obermaier, the activists who took part in the first women's groups and antiauthoritarian nurseries normally shied away from the limelight. In keeping with the gender norms with which they had been socialized, i.e., prioritizing collective needs over their own interests, they habitually downplayed their historical role in starting the second feminist movement. At a commemorative panel discussion twenty years later, the female protagonists confessed how uncomfortable they felt on stage. Sigrid Damm-Rüger, who had famously thrown the tomatoes, argued against any public commemoration of that event and of the feminist movement as a whole. (Her own daughter only learned about the tomato incident at her mother's funeral in 1995.) One of the cofounders of the Frankfurt Weiberrat, Silvia Bovenschen, admitted "a strong tendency to flee" whenever asked to testify in public. Feminist journalist and SDS member Sibylle Plogstedt commented as follows on the self-effacing manner of her fellow campaigners: "There was never even an attempt by the old SDS women to meet and try to work through our own history ... The women did not formulate an interest in presenting their history, and the media did not show any interest in these women either." 50

If the media largely bypassed the story of female ' $68 \mathrm{ers}$, so, too, did mainstream historians. To be sure, there were books on the history of the (first and second) feminist movements that were written, printed, and distributed within the feminist counterculture during the 1970s and 1980s. These niche publications could be astonishingly successful with female audiences. Some of these contributions were penned by Communist or New Left feminists, such as Florence Hervé or Jutta Menschik, whose undergraduate thesis on female emancipation sold thirty-two thousand copies in 1971-1972 alone. Others were literary works, such as Erika Runge's interview collection Frauen: Versuche zur Emanzipation, which sold sixty-six thousand copies between 1969 and 1978; or adult education books, such as Rosemarie Nave-Herz's Geschichte der Frauenbewegung in Deutschland. From 1981 to 1997, the Landeszentralen für politische Bildung distributed five editions of the latter, with every

\footnotetext{
${ }^{48}$ Peter Brügge, "Die rosa Zeiten sind vorbei," Der Spiegel, Nov. 24, 1968.

${ }^{49}$ Uschi Obermaier and Olaf Kraemer, High times: Mein wildes Leben (Munich: Heyne, 2008); Cornils, Writing the Revolution, 141-45.

50 “Antiautoritärer Anspruch und Frauenemanzipation: Die Revolte in der Revolte," transcript of an audiotaped discussion panel at the Free University, Berlin, June 1, 1988 (http://www.infopartisan.net/ archive/1968/29708.html). Cf. Dorothee Damm, "Meine Mutter, die 68erin," in Wie weit flog die Tomate? Eine 68erinnen-Gala der Reflexion, ed. Halina Bendkowski (Berlin: Heinrich-Böll-Stiftung, 1999), 25 .
} 
new edition quickly running out of print. ${ }^{51}$ Influential scholarly works on women's history followed, beginning in the late 1970s. ${ }^{52}$ Through these and other publications, the movement armed itself with feminist ideas and became aware of the long history that had preceded the activism of the late 1960s. Initially, in 1968, historical literature on the women's movement had still been hard to find, as Berlin SDS member Sibylle Plogstedt recalled: "There were hardly any books on the women's movement-you could carry them around with you in a small box when setting up a book table." Even the women in the Frankfurt Weiberrat had not been aware of the nuances of patriarchal repression or even the term sexism. As Silvia Bovenschen explained, "we weren't particularly well equipped ... The bourgeois feminist movement was very repressed and forgotten ... and we did not have a theory of feminism." 53 Over the years, the diffusion of feminist ideas, taken from international and national sources, made a significant difference. ${ }^{54}$

Outside the bubble of the women's movement, historians and newspaper contributors largely reproduced a male narrative in their renditions of the German "1968." In the late 1970s, male SDS veterans began to spin a myth, elevating themselves in the media into a political generation that had more or less single-handedly democratized the Federal Republic from below and broken the stranglehold of their Nazi fathers. ${ }^{55}$ The student unrest of the Sixties was now increasingly understood as a duel between two male age cohorts, adhering to a popular pattern of interpretation first devised by Karl Mannheim in 1928. Mannheim's concept of "political generations" is gendered in its focus on educated male youths, socialized in war or in youth leagues, who then sought to make their mark in the political public sphere by battling each other intellectually. This model of generational formation is difficult to apply to women, whose biographies and experiences tended to be different. "Political generations" are therefore automatically assumed to be masculine. ${ }^{56}$

In the case of West Germany, much of the historiography sees a masculine generational conflict, overshadowed by "the crimes of the fathers," at the heart of the 1968 revolt. Norbert Frei contends, for example, that the young assaulted the "silent patriarchs" of "the Nazi elites." The "68ers, born in the 1940s, were rootless "children of repression"

\footnotetext{
${ }^{51}$ Florence Hervé, ed., Brot und Rosen: Geschichte und Perspektiven der demokratischen Frauenbewegung (Frankfurt/Main: Marxistische Blätter, 1979); idem, Geschichte der deutschen Frauenbewegung (Cologne: PapyRossa, 1982); Jutta Menschik, Gleichberechtigung oder Emanzipation? Die Frau im Erwerbsleben der Bundesrepublik, 2nd ed. (Frankfurt/Main: Fischer, 1972); Erika Runge, Frauen: Versuche zur Emanzipation, 7th ed. (Frankfurt/Main: Suhrkamp, 1978); Nave-Herz, Die Geschichte der Frauenbewegung, 5th ed. (Hannover: Niedersächsische Landeszentrale für politische Bildung, 1997), 7.

${ }^{52}$ See Belinda Davis, "The Personal is Political: Gender, Politics and Political Activism in Modern German History," in Hagemann and Quataert, Gendering Modern German History, 107-27.

53 “Antiautoritärer Anspruch" (see note 50).

${ }^{54}$ The comparison with the Soviet Union points to the key role of feminist ideas. Women there achieved full equality in the labor market, but no feminist discourse developed. As a consequence, gender inequality largely persisted. See Sarah Ashwin, "Women and the Transition from Communism: Between a Rock and a Hard Place," Slavonic and East European Review 71, no. 4 (1993): 712-16.

${ }^{55}$ Axel Schildt speaks of a generation deriving its identity from the press ("Generation am Tropf des Feuilletons"). See "Überbewertet? Zur Macht objektiver Entwicklungen und zur Wirkungslosigkeit der '68er,"' in Reform und Revolte: Politischer und gesellschaftlicher Wandel in der Bundesrepublik vor und nach 1968, ed. Udo Wengst (Munich: Oldenbourg, 2011), 93.

${ }^{56}$ Christina Benninghaus, "Das Geschlecht der Generation: Zum Zusammenhang von Generationalität und Männlichkeit um 1930," in Generationen: Zur Relevanz eines wissenschaftlichen Grundbegriffs, ed. Ulrike Jureit and Michael Wildt (Hamburg: Hamburger Edition, 2005), 127-58. See also Ulrike Jureit, Generationenforschung (Göttingen: Vandenhoeck \& Ruprecht, 2006).
} 
who became estranged from their silent parents. Their actions were always "a moral protest against the guilt of the fathers." 57 Eckart Conze likewise asserts that the young were "morally outraged about the older generations, about their fathers, yes, their grandfathers," causing "conflicts reaching right into the families." 58 As Tony Judt mused, "Many of the men and women born in Germany during the war and immediate post-war years never knew their fathers: who they were, what they had done"; he therefore explained the revolt as a clash with fathers: "If there ever was a generation whose rebellion really was grounded in the rejection of everything their parents represented-everything: national pride, Nazism, money, the West, peace, stability, law and democracy—it was 'Hitler's children,' the West German radicals of the Sixties." 59 A socio-psychological argument is often employed as well: the intergenerational conflicts allegedly escalated because of the parents' emotional coldness and inability to talk about the past. "The price to be paid ... was the generational rebellion of '1968.' The radicalism exhibited then was the result of the psychological damage caused by the intergenerational transfer of the psychological legacy of Nazism." 60 The "68ers were "a generation of emotionally freezing children," whose "key problem" was "a lack of nest warmth." 61

To substantiate such claims, historians often turn to autobiographies and literary texts by well-known male protesters, such as Bernward Vesper (the son of Nazi poet Will Vesper and the husband of terrorist Gudrun Ensslin), K. D. Wolff (the chairman of the West German SDS in 1968), and Hannes Heer (the head of Bonn's SDS and later a leading member of the team responsible for the 1995 Wehrmacht exhibition, which drew public attention to the crimes committed by the German army in World War II). Vesper, Wolff, and Heer publicly maintained that they had turned into rebels because of their Nazi fathers' refusal to talk about their past. ${ }^{62}$ Through extensive media coverage, these isolated cases morphed over time into a generalized generational narrative. '68ers who were interviewed decades after the fact typically rehashed the trope of falling out with their fathers, who were described as having been fellow travellers or perpetrators during the Third Reich. A few historians have taken this generational narrative at face value, basing their arguments on an uncritical analysis of oral history sources. ${ }^{63}$ But, in fact, we now know that most left-wing protesters "did not come from families with a right-wing or particularly conservative outlook." A team that conducted nearly five hundred interviews with former activists across Europe between 2007 and 2011 concluded: "However firmly the notion of generational conflict

${ }^{57}$ Frei, 1968, 78-80, 84, 87, 222.

${ }^{58}$ Conze, Die Suche nach Sicherheit, 337.

${ }^{59}$ Tony Judt, Postwar: A History of Europe since 1945 (London: William Heinemann, 2005), 417. See also Hartmut Kaelble, Sozialgeschichte Europas: 1945 bis zur Gegenwart (Munich: C. H. Beck, 2007), 34; Wienhaus, Bildungswege zu 1968, 38-42.

${ }^{60}$ A. Dirk Moses, German Intellectuals and the Nazi Past (Cambridge: Cambridge University Press, 2007), 69.

${ }^{61}$ Aly, Unser Kampf, 196, 189.

${ }^{62}$ See the 1977 novel by Bernward Vesper, Die Reise (Erfstadt: Area, 2005). For Wolff, see Piotr Oseka, Polymeris Voglis, and Anna von der Goltz, "Families," in Europe's 1968: Voices of Revolt, ed. Robert Gildea, James Mark, and Anette Warring (Oxford: Oxford University Press, 2013), 50. For Heer, see Hodenberg, Das andere Achtundsechzig, 45-52.

${ }^{63}$ See, e.g., Thomas A. Kohut, A German Generation: An Experiential History of the Twentieth Century (New Haven, CT: Yale University Press, 2012), 3-4, 7-8; Karin Wetterau, 68: Täterkinder und Rebellen: Familienroman einer Revolte (Bielefeld: Aisthesis, 2017), 11-12; Hans Kundnani, Utopia or Auschwitz: Germany's 1968 Generation and the Holocaust (London: Hurst, 2009). 
may be established in popular memory, many activists - in Germany and elsewhere-did not experience such a political conflict within their own families." 64 The "68ers only staged the clash with their parents, argues Ulrike Jureit: long after the fact, and in marked contrast to historical reality, they constructed topoi such as emotionally cold parents and the "Auschwitz shock" to allow for a heroic generational narrative. ${ }^{65}$ The same case has been made for the Italian "68ers who, according to ex-activist and historian Luisa Passerini, "chose to be orphans" by overemphasizing generational tensions in their respective families. ${ }^{66}$

To quote Claus Leggewie, such "late oedipal scenarios" of paternal repression were also widespread in fictional literature. ${ }^{67}$ Beginning in the early 1970s, the new genre of Väterliteratur explored the traumatic consequences that this type of conflict had supposedly left on the younger generation in West Germany. It was mainly young male authors who bewailed the silence and the guilt, but also the traumatic loss of their Nazi fathers in novels and plays. ${ }^{68}$ It is a genre that reprises old literary tropes going back centuries. ${ }^{69}$

There are several problems with this Don Carlos myth. It understands the young as active and the old as passive. It takes for granted that the Nazi past was at the core of any generational conflict. It wrongly implies that generational conflict was a widespread reality in families in the 1960s. It also tends to resort to collective psychology and to conflate political generations with familial generations. In fact, it was common for " 68 ers to join in the selective silence about the Nazi past in West German families. ${ }^{70}$ It is also worth examining the gendered aspect of the myth. The generational version of events, obsessed as it is with fathers, disregards female experience and agency. It leads to an overemphasis on intergenerational conflict in the historical narrative, thereby underrepresenting the virulence of gender conflict among the younger age cohort and leaving relations between daughters and parents underexplored.

In fact, if we investigate relations between mothers and daughters in the 1960s-a topic that needs more research - all indications point to arrangements that mostly avoided open conflict and that, at times, included mutual forms of support in conflicts with fathers and grandfathers. The mothers were no longer role models whose life scripts could easily be copied, but many nevertheless remained close confidantes. In polls conducted at the time, a third of twenty-three-year-old women named their mothers as the person they trusted most; another fifth named both parents. Four out of five young people described their mothers as "approachable" and "emotionally positive." The percentage was highest in academic, white-collar, and civil servant families. ${ }^{71}$ These findings contradict the popular

\footnotetext{
${ }^{64}$ Oseka, Voglism, and von der Goltz, "Families," 51.

65 Jureit, Generationenforschung, 92, 119-20. Also see Kurt Lüscher and Ludwig Liegle, Generationenbeziehungen in Familie und Gesellschaft (Konstanz: UVK, 2003), 29-30, 251-52.

${ }^{66}$ Luisa Passerini, Autobiography of a Generation: Italy, 1968, trans. Lisa Erdberg (Middletown, CT:

Wesleyan University Press, 1996), 27. See also Joseph Maslen, "Autobiographies of a Generation? Carolyn Steedman, Luisa Passerini and the Memory of 1968," Memory Studies 6, no. 1 (2013): 30.

${ }^{67}$ Claus Leggewie, "A Laboratory of Postindustrial Society: Reassessing the 1960s in Germany," in 1968: The World Transformed, ed. Philipp Gassert, Carole Fink, and Detlef Junker (Cambridge: Cambridge University Press, 1998), 281.

${ }^{68}$ For example, see the novels by Peter Schneider, Günter Kunert, Peter Härtling, or Niklas Frank. Also see Hannes Heer, "Literatur und Erinnerung: Die Nazizeit als Familiengeheimnis," Zeitschrift für Geschichtswissenschaft 53, no. 9 (2005): 809-35; Seegers, Vati blieb im Krieg, 20-21.

${ }^{69}$ Domenica Tölle, Altern in Deutschland 1815-1933: Eine Kulturgeschichte (Grafschaft: Vektor, 1996).

${ }^{70}$ Hodenberg, Das andere Achtundsechzig, 45-76.

${ }^{71}$ Pfeil, Die 23jährigen, 111-13, 136; for similar findings from 1964, see Viggo Graf Blücher, Die Generation der Unbefangenen: Zur Soziologie der jungen Menschen heute (Düsseldorf: Diederichs, 1966), 102.
} 
stereotype of "Hitler's willing mothers," who allegedly ruled over their "68er offspring as cold and heartless disciplinarians who traumatized them in the process. ${ }^{72}$ During the summer of 1968, psychologists interviewed thirty-nine mothers between ages thirty-five and fifty-six living in the Cologne-Bonn region. Most mothers saw their teenage or adult daughters as partners: they mutually negotiated many everyday decisions, from miniskirts to parties, and crucially supported their wish to attain higher education and choose their vocation freely. Mothers who felt that their own educational chances and career options had been stymied often helped their daughters earn the high school leaving certificate (Abitur) and even go to university, frequently against the reservations of the fathers. ${ }^{73}$

Still, many female '68ers mainly thought of their mothers as depressed housewives who were dominated by their husbands. As Mechtild Düsing, then a student in Münster, put it: "We no longer wanted to be like our own mothers, who had only lived for the husband ... One's own mother, that was the horror image!"74 Like Helke Sander of the Berlin Aktionsrat, who called the mothers "eerily ... subservient," many feminist activists criticized the ritualized humility and apolitical stance of older women. "Doing it differently from the way your mother did" became a rallying cry for young feminists who publicly vowed no longer to be dominated by marriage and family. For example, author Erika Runge, born in 1939, embarked on a successful interview project that looked at the life histories of seventeen German women because she "needed role models. My mother couldn't be one for me, I didn't want to live like her." 75 In public, then, female '68ers delineated themselves clearly from their mothers, whom they characterized as apolitical, submissive, "depersonalized" housewives-but not as Nazis.

A closer look at the biographies of mothers and daughters shows, however, that, in reality, change was more gradual than radical. Women who were born around 1940 tended to live a life model in which periods of employment came before and after childrearing - just like that of their mothers. But the younger generation was better at theorizing and publicly defending their career phases as motivated by individual choices. By contrast, their mothers often veiled periods of paid employment as necessary contributions to the family collective-because they did not want to challenge the traditional marriage model. ${ }^{76}$ Overall, most middleaged women in the 1960s were somewhat less patriarchally-minded than the generation of their grandmothers, and they maintained close relationships with their daughters. In private, then, generational conflict between female '68ers and their mothers was much less pronounced than public statements might suggest. Just as important, the Nazi past of the mothers or grandmothers was hardly ever addressed.

\footnotetext{
${ }^{72}$ The phrase is from Sabine Bode, Die vergessene Generation: Die Kriegskinder brechen ihr Schweigen (Stuttgart: Klett-Cotta, 2016), 149; see also Barbara Stambolis, Töchter ohne Väter: Frauen der Kriegsgeneration und ihre lebenslange Sehnsucht (Stuttgart: Klett-Cotta, 2012), 87-89; Barbara Stambolis, Aufgewachsen in "eiserner Zeit": Kriegskinder zwischen Erstem Weltkrieg und Weltwirtschaftskrise (Giessen: Psychosozial, 2014), 136.

${ }^{73}$ The project was led by Helga M. Merker and the transcripts are available in the Historisches Datenzentrum, Universität Halle-Wittenberg, Bolsa, File A 17; Hodenberg, Das andere Achtundsechzig, $132-41$.

74“68er an Rhein, Ruhr und Weser," dir. Carsten Günther, broadcast on Westdeutscher Rundfunk, May 9 and 16, 2008. See also the activists Elke Regehr, Sigrid Fronius, Sarah Haffner, Helke Sander, and Elsa Rassbach in Kätzel, Die 68erinnen, 99, 27, 21, 141-42, 161, 62, 96.

${ }^{75}$ Silies, Liebe, Lust und Last, 343. See also Kätzel, Die 68erinnen, 202, 243, 255; Runge, Frauen, 271.

${ }^{76}$ Thon, Frauenbewegung im Wandel, 260-61, 279, 413-17.
} 
Even if our understanding of the relationship between mothers and daughters is still sketchy, the addition of gender nevertheless changes the established narrative of "1968." 77 Within families and in the private sphere, gender conflict seems to have been at least as prominent, and possibly more so, than generational conflict was. This has repercussions for our understanding of what defines the political generation of the "68ers, and of what the protest movement of the 1960s achieved in the long term.

The generational belonging of male and female "68ers was defined in different ways. Many men who were born in the 1940s and early 1950s began to feel a part of this generation when, years after the events, they actively or passively took part in mass media debates about the role of their age cohort in the history of the republic. Female "68ers did not communicate to the same extent in public about their historical role and biographic commonalities. What bound these women together, beyond having been born around the same time, was not the "narrated" but rather the "silent generational experience": direct, life-changing experiences such as the contraceptive pill, women's groups, or battles with male partners over chores, childcare, and career choices. ${ }^{78}$ The concept of a "silent" generation differs in several ways from the established Mannheimian pattern of political generations. It allows for formative experiences in the private sphere, it is not restricted to the educated elites, and it is not as dependent on mediated discourses. These features enable us to extend the concept to include women, and thus to define the "68ers as a generation of both genders.

\section{Contested Legacy}

It has almost become a truism among historians that the protest movement "failed politically but succeeded culturally," i.e., that it could not incite a socialist revolution, but that it did set in motion a lifestyle revolution that, over the long term, changed the republic beyond recognition..$^{79}$ In concluding his account of the 1960s, Norbert Frei, for example, argues that a sea change in "the face and the mentality of the republic" was the protesters' lasting achievement: "From now on, it was not exactly ubiquitous but it was certainly possible to witness in a Swabian village a skilled worker with slightly longer hair pushing a pram, his female partner not present - and likewise a young female secretary from a Hessian town holidaying in Spain on her own." Frei's examples are taken from the private sphere and are about "doing gender," i.e., about the myriad ways in which men and women express and negotiate their gender identities. Frei's book nevertheless devotes very little space to gender conflict and gender identities. ${ }^{80}$ If one subscribes to the argument of political failure and cultural success, one should at least acknowledge that "cultural" in this instance largely means "gendered," and that it is the female "68ers who should mainly be credited with bringing about this lifestyle revolution. If the most fundamental consequences of the Sixties revolt were changes to the way in which West Germans "did gender," then it was, for the most part,

\footnotetext{
${ }^{77}$ Cf. Lerke Gravenhorst and Carmen Tatschmurat, eds., Töchter-Fragen: NS-Frauen-Geschichte (Freiburg im Breisgau: Kore, 1990).

${ }^{78}$ On the pill, see Silies, Liebe, Lust und Last, 427. For the process of male-narrated generational belonging, see Benjamin Möckel, Erfahrungsbruch und Generationsbehauptung: Die "Kriegsjugendgeneration" in den beiden deutschen Nachkriegsgesellschaften (Göttingen: Wallstein, 2014).

${ }^{79} \mathrm{Cf}$. Ingrid Gilcher-Holtey, "Einleitung," in "1968"-eine Wahrnehmungsrevolution? HorizontVerschiebungen des Politischen in den 1960er und 1970 Jahren (Munich: Oldenbourg, 2013$), 7$.

${ }^{80}$ Frei, 1968, 228. Also see Candace West and Don H. Zimmermann, "Doing Gender," Gender and Society 1, no. 2 (1987): 125-51; special issue of Gender and Society 23, no. 1 (2009).
} 
the female "long march" through the marriages and families of the republic that brought about change. It was the anti-patriarchal thrust of the protest movement that formed its essential legacy; this jibed well with the movement's overarching antiauthoritarianism.

If one widens the perspective beyond Germany, one detects the first stirrings of a genderaware reassessment of the history of the 1960s. Looking at North America, Latin America, Japan, and Western Europe, Sara M. Evans has argued that "gender insurgency was a central component of the rebellions of men as well as women across the globe." She, too, stresses "that feminism and dramatic challenges to gender relations were among the primary legacies of the activism of the "1968 generation," even if most historiography still gives "short shrift to women." The journal L'Homme similarly ran a special issue highlighting the absence of the category "gender" in the scholarship on " 1968 " in the Dutch, Austrian, Swiss, German, and Eastern European settings. ${ }^{81}$ Historians of May 1968 in France have also begun to attack how the events have been reduced to a Parisian story of educated, leftist elites that bypasses the workers, the masses, and the provinces (but without primarily focusing on gender). ${ }^{82}$

It seems, then, that a reassessment of the historical importance of postwar female activism is on the international agenda. The fiftieth anniversary of "1968" nevertheless led to contentious discussion in Germany. Responding to a book I wrote that highlights the role of women in the late 1960s, Wolfgang Kraushaar and Axel Schildt denied that "1968" sparked the West German second feminist movement. Kraushaar concedes that "the female side was underexposed in the historiography to date," but he attacks what he sees as an attempt to rewrite the student movement as a "movement of female students" (Studentinnenbewegung): "The new women's movement only formed in 1971 in the context of the anti-abortion campaign ... Beforehand, there were only tiny groups and circles, but no movement in the true sense of the word [im eigentlichen Sinne]." Schildt similarly acknowledges that "there was doubtless a marginalization of the female part of the revolt in public perception," but then criticizes "the backdating of the genesis of a new women's movement" and the inclusion of "tomato tosses by SDS-heroines," which, he claims, have already been "cited to death." 83 In trying to shift the women's movement into the 1970s, and thus keep "1968" assigned to male protagonists, Kraushaar and Schildt unintentionally reproduce the views of contemporary male New Leftists, who saw women's struggle for equality as the "minor contradiction" (Nebenwiderspruch). They also reprise Alice Schwarzer's version of history, which maintains that the second feminist movement began only with the 1971 campaign to legalize abortion

\footnotetext{
${ }^{81}$ Sara M. Evans, "Sons, Daughters, and Patriarchy: Gender and the 1968 Generation," American Historical Review 114, no. 2 (2009): 331-32. Historians in Italy, following Luisa Passerini’s works, began to pay attention to female agency somewhat earlier. See Maud A. Bracke, Women and the Reinvention of the Political: Feminism in Italy, 1968-1983 (New York: Routledge, 2014); idem, “'Women's 1968 Is Not Yet Over': The Capture of Speech and the Gendering of 1968 in Europe," American Historical Review 123, no. 3 (2018): 753-57; Fiammetta Balestracci, “The Influence of American Sexual Studies on the "Sexual Revolution' of Italian Women," in Children by Choice? Twentieth Century Value Changes in Human Reproduction and Family Planning, ed. Ann-Katrin Gembries, Isabel Heinemann, and Theresia Theuke (Munich: de Gruyter, 2018), 145-61; L'homme 20, no. 2 (2009).

${ }^{82}$ Kristin Ross, May ' 68 and Its Afterlives (Chicago, IL: University of Chicago Press, 2008); Michelle Zancarini-Fournel, Le moment 68: Une histoire contestée (Paris: Editions du Seuil, 2008); Julian Jackson, “The Mystery of May 1968," French Historical Studies 33, no. 4 (2010): 625-53.

${ }^{83}$ Wolfgang Kraushaar, "Umso schlimmer für die Tatsachen," Süddeutsche Zeitung, April 25, 2018; Axel Schildt's review in Sehepunkte 18, no. 5 (2018) (http://www.sehepunkte.de/2018/05/31368.html). For media coverage of the debate, see Christian Geyer, "Wie weiblich war 1968?," Frankfurter Allgemeine Zeitung, April 30, 2018.
} 
that she had initiated as a young journalist. For her, the late 1960s women's groups were but a "deceptive illusion" (trïgerischer Schein) and "premature spring [Vorfrühling] of the women's movement" because they had allegedly never left the "student ghetto." 84 It is true that, during the 1970s, the West German feminist movement grew massively and became less socially exclusive and heteronormative. Its public protests and media coverage multiplied, and it added a new emphasis on women's bodily and sexual autonomy. Nevertheless, the key elements of the second wave of the women's movement were already present in 1968. Female '68ers found their voice as political actors; they practiced the protest forms of symbolic and direct action; they argued that the private was political; they organized in informal, gender-separatist groups; they founded anti-authoritarian nurseries. There were also significant personal continuities between the female activism of 1968 and the 1970s. For example, Helke Sander, whose speech had enraged SDS "machos" in 1968, was active in the Berlin women's group Brot und Rosen and in the campaign against the pill during the 1970s. Sarah Haffner initiated the first safe house for battered women, in Berlin in 1976. Several women from the early women's groups in that city participated in the first salvo of Schwarzer's campaign to legalize abortion in the Stern in 1971 by confessing, "I had an abortion." 85 Why erect an artificial distinction between "1968" and the women's movement of the 1970s?

The example of " 1968 " shows that historians could integrate female agency into the master narratives of contemporary history in many ways. Publications in post-1945 women's and gender history are too often considered "niche." They need to play a greater role in master surveys. Areas with "feminine" connotations deserve more attention from mainstream historians, particularly conflicts and changes in the private sphere and the family, which were entwined with politics and wider society. Historians could also focus more intently on "doing gender" and on how it changed over time. They could resist buying into contemporary gendered dichotomies, such as a feminized "cultural" versus a masculine "political" realm-recognizing that changes in the so-called cultural sphere were often political and impactful. The tendency to narrate contemporary history as a duel between political generations (between '45ers and "68ers, possibly with '33ers thrown into the mix) needs to be recognized as an inherently male perspective. ${ }^{86}$

We also lack studies on middle-aged and elderly women, on conservative and Christian women, as well as on working-class women; these groups are largely invisible in the contemporary historiography. ${ }^{87}$ The Federal Republic's commemorative culture is also gendered because of how it privileges male recollections. Local and regional oral history projects

\footnotetext{
${ }^{84}$ Schulz, Der lange Atem der Provokation, 187; "über uns" (editorial) and Chantal Louis, "Die 68erinnen," EMMA no. 3 (May 2018), 4, 84-88. See also Imke Schmincke, "Von der Politisierung des Privatlebens zum neuen Frauenbewusstsein: Körperpolitik und Subjektivierung von Weiblichkeit in der neuen Frauenbewegung Westdeutschlands," in Paulus, Silies and Wolff, Zeitgeschichte als Geschlechtergeschichte, 297-317.

${ }^{85}$ Kätzel, Die 68erinnen, 157, 175-77, 193. See also Schulz, Der lange Atem der Provokation, 149; Ilse Lenz, "Das Private ist politisch? Zum Verhältnis von Frauenbewegung und alternativem Milieu," in Reichardt and Siegfried, Das alternative Milieu, 375-404.

${ }^{86}$ See, e.g., Aly, Unser Kampf; Moses, German Intellectuals and the Nazi Past; Christina von Hodenberg, Konsens und Krise: Eine Geschichte der westdeutschen Medienöffentlichkeit 1945-1973 (Göttingen: Wallstein, 2006).

${ }^{87}$ An exception is Vera Neumann, Nicht der Rede wert: Die Privatisierung der Kriegsfolgen in der frühen Bundesrepublik: Lebensgeschichtliche Erinnerungen (Münster: Westfälisches Dampfboot, 1999).
} 
and exhibitions need to represent more fully women's voices and activism alongside that of men. Thus far, interview collections and exhibition catalogues on late 1960s protest underrepresent women, and they rarely ask their subjects about clashes and negotiations over gender. Typical examples of this include projects in Bonn and Berlin that marked the fortieth anniversary of "1968." 88

Finally, master narratives of the Federal Republic that measure success against ideals of Western democracy could rethink how the struggle against patriarchal structures and gender inequality relates to their overarching arguments. To what extent did postwar processes of "Westernization" and "liberalization" rely on, advance, or reduce male domination? How does the emancipation of women, as a century-long, continuous, but uneven process peaking between roughly 1968 and the early 1980s, affect the periodization of post-1945 West German history? The long Sixties, spanning from the last third of the 1950s to about 1973, have often figured as a decade of dynamic change, cultural experimentation, and grass-roots democratization, during which the face of the republic was transformed. The Seventies have been framed, by contrast, as an era of structural rupture, when economy, labor, science, and intellectual debates adjusted to new conditions "after the boom." Both the debates about the character of the long Sixties and the era "after the boom" could benefit from a more meaningful inclusion of patriarchal continuities and feminist agency in twentieth-century history. ${ }^{89}$ We need to overcome the compartmentalization of women's and gender history when writing the story of the Federal Republic. Only then can we assess more fully its "success" and its relationship to the West.

Queen Mary University of London

\footnotetext{
${ }^{88}$ The Bonn project ran in 2005-2006; see Horst-Pierre Bothien, Protest und Provokation: Bonner Studenten 1967-1968 (Essen: Klartext, 2007). This exhibition omitted mention of the Arbeitskreis Emanzipation, and, of twenty-one interviewees, only three were women. The 2008 exhibition "68-Brennpunkt Berlin" by the Bundeszentrale für politische Bildung similarly overlooked the Aktionsrat and the Kinderläden. Ute Kätzel ran a counterproject focused on female interviewees since 1998: Ute Kätzel, "Vorwort zur Neuauflage," in Kätzel, Die 68erinnen, ii. For the role of women in commemorative culture, see also Elizabeth Heineman, "The Hour of the Woman: Memories of Germany's 'Crisis Years' and West German National Identity," American Historical Review 101, no. 2 (1996): 354-95.

${ }^{89}$ Cf. Julia Paulus, Eva-Maria Silies, and Kerstin Wolff, "Die Bundesrepublik aus geschlechterhistorischer Perspektive," in Paulus, Silies, and Wolff, Zeitgeschichte als Geschlechtergeschichte, 13-20; Lutz Raphael and Anselm Doering-Manteuffel, Nach dem Boom: Perspektiven auf die Zeitgeschichte seit 1970 (Göttingen: Vandenhoeck \& Ruprecht, 2012).
} 